\title{
Fracture toughness evaluation of supermartensitic stainless steel submitted to cathodic protection in seawater environment
}

\author{
Avaliação da tenacidade à fratura do aço inoxidável supermartensítico \\ submetido à proteção catódica em água do mar \\ Gabriel Pieta Dias
}

Eng. Metalúrgico, Laboratório de Metalurgia Física (LAMEF), Programa de Pós-graduação em Engenharia de Minas, Metalúrgica e de Materiais (PPGEM), UFRGS Av. Osvaldo Aranha, 99, s. 610 Porto Alegre, RS, Brasil CEP 90035-190 gdias@demet.ufrgs.br

Afonso Reguly

Prof. Dr. Eng, Laboratório de Metalurgia Física (LAMEF), Programa de Pós-graduação em Engenharia de Minas, Metalúrgica e de Materiais (PPGEM), UFRGS reguly@demet.ufrgs.br

Telmo Roberto Strohaecker

Prof. Dr. Eng, Laboratório de Metalurgia Física (LAMEF), Programa de Pós-graduação em Engenharia de Minas, Metalúrgica e de Materiais (PPGEM), UFRGS telmo@demet.ufrgs.br

\begin{abstract}
Supermartensitic stainless steels (SSS) have been applied in oil and gas industries for flowline material as an alternative for both duplex stainless steels and carbon steels with inhibitor. SSS show greater toughness, corrosion resistance and weldability properties when compared to conventional martensitic stainless steels. However, when protected cathodically in seawater environment they can be susceptible to hydrogen embrittlement due to hydrogen charging. The present study evaluates the fracture toughness of SSS submitted to cathodic protection in seawater environment at a potential of steel "over-protection". Incrementally step loading technique was used in the SSS fracture toughness evaluation. The results show a significant drop in the fracture toughness of steel in the studied environment.
\end{abstract}

Key words: supermartensitic stainless steel, cathodic protection, fracture toughness.

\section{Resumo}

Os aços inoxidáveis supermartensíticos (AIS) vêm sendo aplicados em linhas de condução na indústria de petróleo e gás aparecendo como uma alternativa aos aços inoxidáveis duplex e aos aços carbono com uso de inibidores. Estes aços exibem maiores propriedades de tenacidade, resistência à corrosão e soldabilidade quando comparados aos aços inoxidáveis martensíticos convencionais. Porém, quando protegidos catodicamente em água do mar estes aços podem ser suscetíveis à fragilização por hidrogênio devido ao carregamento com hidrogênio. O presente estudo avalia a tenacidade à fratura do AIS submetido à proteção catódica em água do mar em um potencial de "super-proteção" do aço utilizando a técnica de step loading com incremento de carregamento. Os resultados mostram uma significante queda na tenacidade à fratura do aço no ambiente estudado.

Palavras-chave: aço inoxidável supermartensítico, proteção catódica, tenacidade à fratura. 
Fracture toughness evaluation of supermartensitic stainless steel submitted to cathodic protection in seawater environment

Gabriel Pieta Dias, Afonso Reguly, Telmo Roberto Strohaecker

\section{Introduction}

The current increasing in oil and gas production from deeper wells impose more severe and deleterious operation conditions over the material used in the petroleum industry (Ramirez, 2007; Miyata et al., 2006). The presence of specimens like organic acids, chlorides, $\mathrm{CO}_{2}$ and $\mathrm{H}_{2} \mathrm{~S}$ has a sharp effect in the corrosion of production fields (Marchebois et al., 2007). Since the nineties, low carbon martensitic stainless steels, called supermartensitic stainless steels (SSS), have been developed for flowline applications in $\mathrm{CO}_{2}$ content environments contributing to oil and gas industries as an alternative to replace expensive duplex stainless steels or carbon steels with inhibitors (Miyata et al., 2007). The SSS combine low carbon content together nickel and molybdenum additions uniting, thus, high corrosion resistance and good weldability in order to achieve superior properties in relation to conventional $13 \% \mathrm{Cr}$ steels (Marchebois et al., 2007). Moreover, SSS were developed with greater general corrosion resistance in $\mathrm{CO}_{2}$ and high temperatures, with SSC resistance in little $\mathrm{H}_{2} \mathrm{~S}$ amount environments, being a fundamental characteristic for their desirable application (Ramirez, 2007). Consequently, many studies have been carried in order to establish a better knowledge about SSS behavior and the viability of their application in oil and gas transport (Rogne et al., 1999).

The external side of flowlines in contact with seawater is usually protected against corrosion by cathodic protection (Pourbaix, 1999). Since this protection can promote hydrogen evolution in these regions, it can be considered a hydrogen source (Stroe, 2006). Hydrogen exhibits a deleterious effect in many materials under several environments and service conditions. Thus, degradation of mechanical properties and hydrogen induced cracking, generally denominated hydrogen embrittlement, has been object of many studies (Gingell, 1997).

SSS are susceptible to this phenomenon in seawater environments when submitted to cathodic protection (Rogne et al., 1999). This susceptibility is generally increased with increase mechanical resistance of steels (Nagumo et al., 2001) and martensitic steels are more susceptible to hydrogen degradation (Gingell, 1997). An example of favorable service condition to hydrogen embrittlement phenomenon is pipelines working in acid environments, many times in presence of $\mathrm{H}_{2} \mathrm{~S}$, present in oil and gas production of some fields (Gingell, 1997). However, reported studies suggest SSS are susceptible to hydrogen embrittlement in hydrogen charged conditions even in presence of no aggressive environment (Bala Srinivasan et al., 2004). In this way, this work aimed an evaluation of SSS behavior in conditions prone to environment assisted cracking.

\section{Material and Methods}

The chemical composition of SSS studied can be observed in Table 1. The microstructural characterization was performed using Optical microscopy and standard metallographic practice. The presence of retained austenite in martensitic matrix was determined by X-ray diffraction in a Philips $X^{\prime}$ Pert MPD diffractometer using $\mathrm{CuK}_{\alpha}$ radiation operating at $40 \mathrm{kV}$ and $50 \mathrm{~mA}$. The scanner mode was used to cover a degree range from $47^{\circ}$ to $103^{\circ}$ in $0.05^{\circ}$ increments.

Estudos Tecnológicos - Vol. 4, n 3: 146-156 (set/dez. 2008) 
Fracture toughness evaluation of supermartensitic stainless steel submitted to cathodic protection in seawater environment

Gabriel Pieta Dias, Afonso Reguly, Telmo Roberto Strohaecker

The SSS mechanical properties were evaluated by microhardness test and fracture mechanics tests. To evaluate the steel fracture toughness in the as-received condition fracture mechanics compact tension (CT) specimens were removed from a seamless pipeline of approximate 0.5in of thickness. CT specimens with $6.10 \mathrm{~mm}$ of thickness were designed according to ASTM E399-90 (American Society for Testing and Materials, 1997).

Table 1: Chemical composition of SSS.

\begin{tabular}{|cccc|}
\hline Element & Mass \% & & \\
\hline $\mathbf{C}$ & 0,013 & $\mathbf{N b}$ & 0,012 \\
$\mathbf{C r}$ & 12,45 & $\mathbf{T i}$ & 0,4 \\
$\mathbf{N i}$ & 5,21 & $\mathbf{V}$ & 0,12 \\
$\mathbf{M o}$ & 2,02 & $\mathbf{W}$ & 0,017 \\
$\mathbf{S i}$ & 0,29 & $\mathbf{P}$ & 0,021 \\
$\mathbf{M n}$ & 0,48 & $\mathbf{S}$ & $<0,001$ \\
$\mathbf{A l}$ & 0,05 & $\mathbf{P b}$ & $<0,002$ \\
$\mathbf{C o}$ & 0,06 & $\mathbf{S n}$ & 0,007 \\
$\mathbf{C u}$ & 0,12 & $\mathbf{F e}$ & Bal. \\
\hline
\end{tabular}

The fracture toughness tests were conduced in air and in seawater environment both at room temperature (approximated $23^{\circ} \mathrm{C}$ ) using CT specimens. Air tests were carried out submitting CT specimens to monotonic loading until fracture using a MTS 810 machine. These tests supplied results in stress intensity factor (K) versus crack opening displacement (COD) graphics, where COD is monitored by clip gage extensometer.

The fracture toughness environment assisted tests were carried out using incrementally step loading technique with prescribed load. In these tests, CT specimens were tensile loaded in increasing load steps until fracture while they were submitted full time to cathodic protection by impress current at the potential of $-1100 \mathrm{mV}_{\mathrm{xSCE}}$ submersed in synthetic seawater. The procedure of step loading tests was constituted in initials three loading steps of five units of $\mathrm{K}(\mathrm{MPa} \sqrt{\mathrm{m}})$. After this initial cycle, the applied load on steps became one unit of $\mathrm{K}$ until specimens fracture. The imposed loading on steps was kept constant for 24 hours. The test ending provided $\mathrm{K}$ values of fracture promoting an evaluation of SSS fracture toughness in the studied environment. The fractographic analyses of CT specimens were carried out by scanner electronic microscopy (SEM) in order to obtain information about the micromechanisms involved on fracture processes.

\section{Results and Discussion}

The SSS microstructure in the as-received condition consisted of tempered martensite exhibiting large amounts of precipitates (carbides and nitrites (Rožnovská et al., 2005)) and $\delta$-ferrite as can be observed in Figure 1. The SSS microhardness was about 300HV. Due to the high titanium content of steel, is expected the presence of $\mathrm{Ti}(\mathrm{C}, \mathrm{N})$ precipitates which are important to the corrosion resistance for its role in the prevention of chromium and molybdenum carbonitrides formation. However, some intermetallic 
Fracture toughness evaluation of supermartensitic stainless steel submitted to cathodic protection in seawater environment

Gabriel Pieta Dias, Afonso Reguly, Telmo Roberto Strohaecker

compounds such as TiNi can result from high titanium additions inducing a secondary hardening in steel (Kondo et al., 1999). The presence of $\delta$-ferrite in the microstructure could be consequence either from a too elevated austenitization temperature during fabrication process or an inadequate balance between alloy elements in the steel resulting in a dual-phase microstructure. A re-austenitization of steel at $1000^{\circ} \mathrm{C}$ for 30 minutes followed by air quench resulted in some reduction of ferrite phase, however reported studies showed that the dissolution of $\delta$-ferrite appear to be a slow process at solution temperatures (Carrouge et al., 2004). Since $\delta$-ferrite is an undesirable phase in SSS (Kondo et al., 1999), the properties and the quality of as-received steel might be affected by the presence of this phase in the microstructure.

X-ray diffraction analysis was carried out in SSS to identify the presence of any retained austenite in microstructure. The XRD patterns of SSS sample are shown in Figure 2. The results detected the presence of austenite in the martensitic matrix even though its identification is not possible by optical microscopy. This austenite reformed during the tempering process remains stable on cooling improving the steel toughness properties (Rožnovská et al., 2005).

The results of fracture toughness in air obtained by monotonic test are presented on stress intensity factor versus cracking opening displacement plots (Figure 3). SSS exhibited a great ductile behavior exhibiting a fracture within plastic regime. The large amount of $\delta$-ferrite in the steel was not harmful to ductility and, consequently, to fracture toughness of material at room temperature as observed in Figure 3. This result agreed with reported by Carrouge et al. (2004) that observed similar notch toughness for both SSS composed of fully martensite and martensite $+14 \%$ ferrite microstructures tested at $0^{\circ} \mathrm{C}$ both showing ductile ruptures. The harmful effect of $\delta$-ferrite in the toughness of steel just appeared at lower temperatures with decreasing in the ductile to brittle transition temperature.

Since fracture of specimens in air occurred in the plastic regime it leads to necessity of use of elastic-plastic fracture mechanic concepts to determination fracture toughness value, such as CTOD or Jintegral methods (Anderson, 1995). However, in order to compare the steel behavior in air and assisted by environment, it was considered the maximum $\mathrm{K}$ value obtained in the monotonic test in air, designed as apparent $\mathrm{K}$ value ( $\mathrm{K}_{\text {apparent }}$ ). Thus, the maximum load supported by the material was $1.231 \mathrm{Kgf}$, which corresponding to $\mathrm{K}_{\text {apparent }}$ about $128 \mathrm{MPa} \sqrt{\mathrm{m}}$. 
Fracture toughness evaluation of supermartensitic stainless steel submitted to cathodic protection in seawater environment

Gabriel Pieta Dias, Afonso Reguly, Telmo Roberto Strohaecker
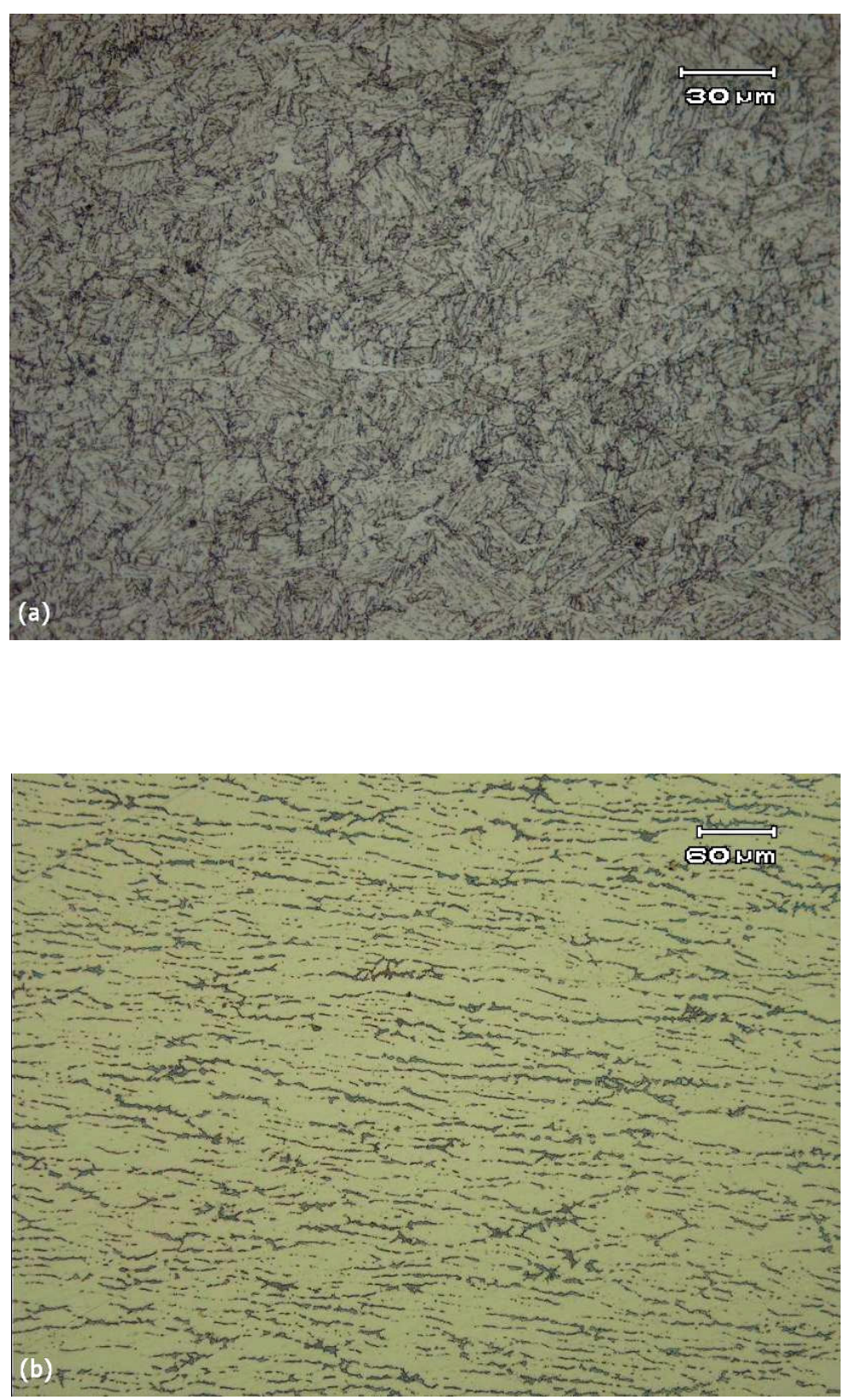

Figure 1: Supermartensitic stainless steel microstruture in the as-received condition. OM. (a) Tempered martensite. Etchant: Villella's. (b) $\delta$-Ferrite distribution (light grey). Etchant: $\mathrm{KOH}$ Electrolytic. 


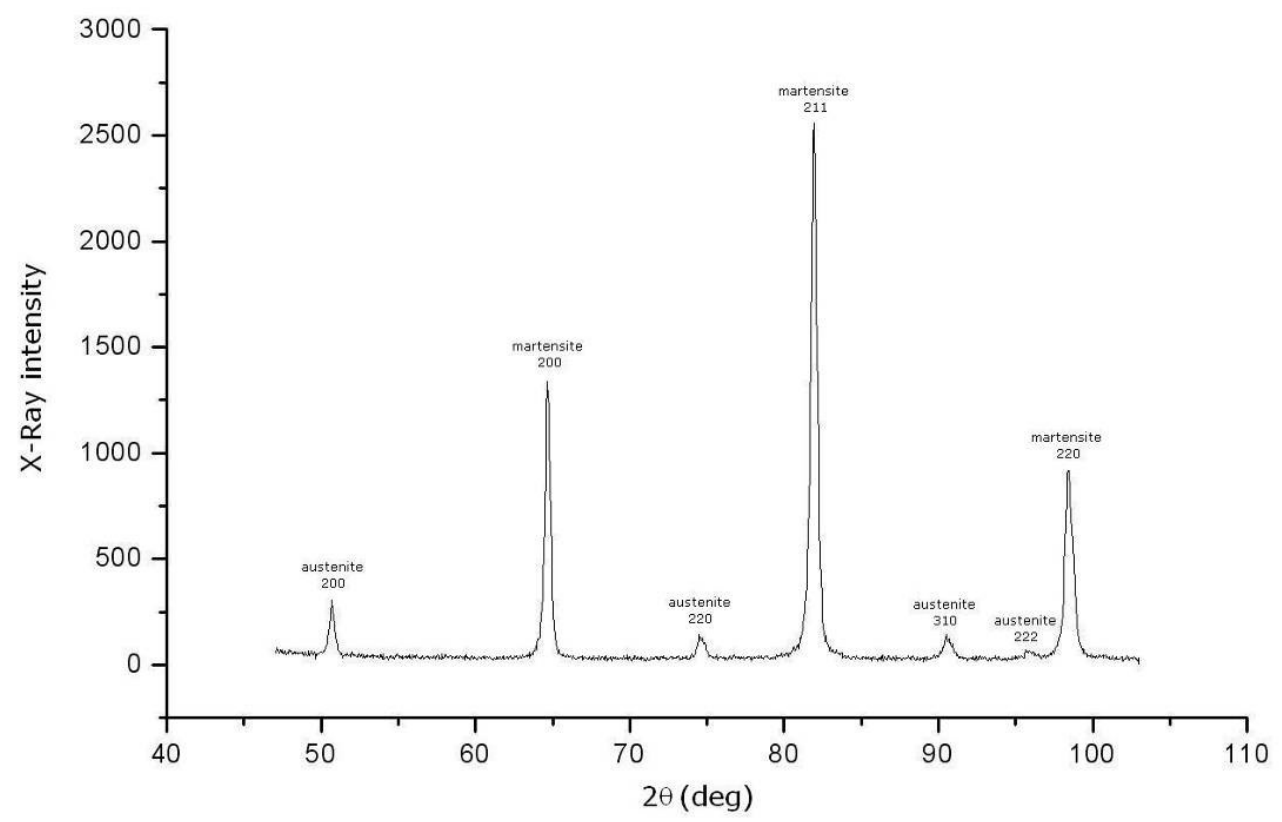

Figure 2: XRD pattern of SSS.

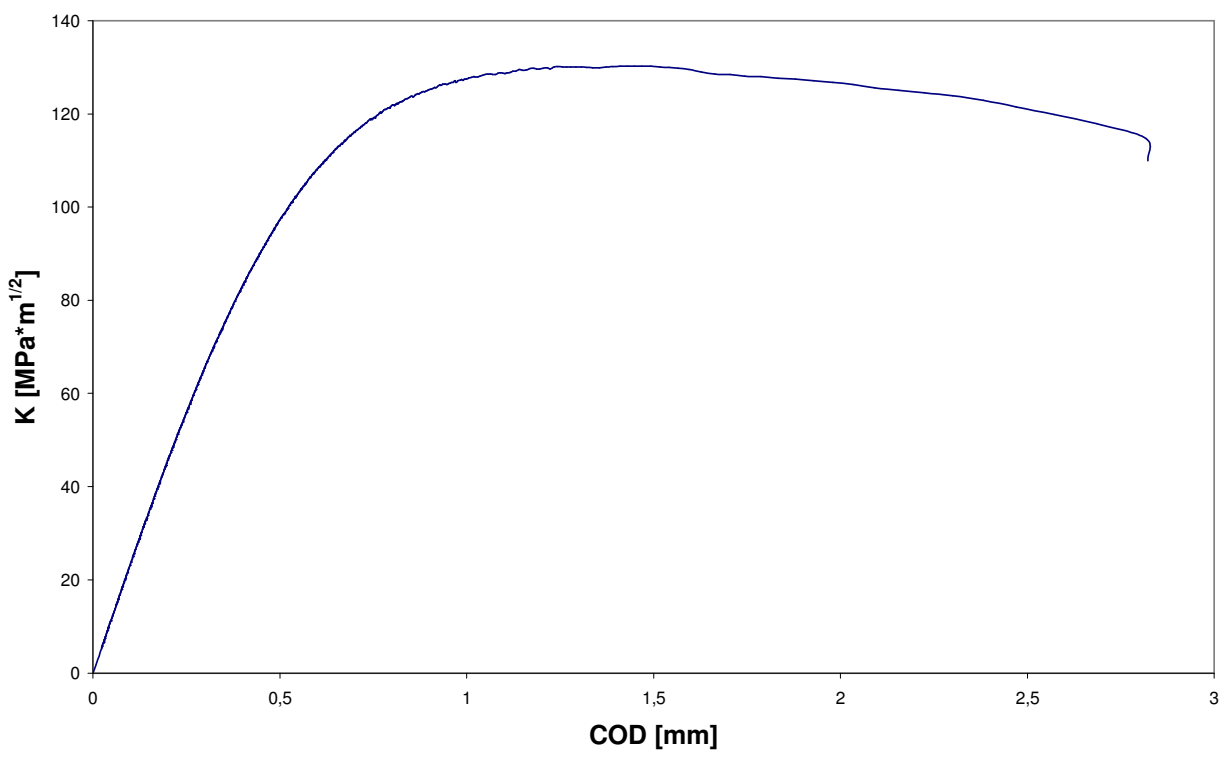

Figure 3: Resulted graphic from monotonic test in air.

The fractographic analysis of CT specimens tested in air showed a ductile fracture by microvoid coalescence (dimples) as observed in Figure 4. This typical dimple appearance may be also attributed to the 
Fracture toughness evaluation of supermartensitic stainless steel submitted to cathodic protection in seawater environment

existence of internal interfaces due austenite particles and precipitates, which may act as void nucleation sites (Bilmes et al., 2001).
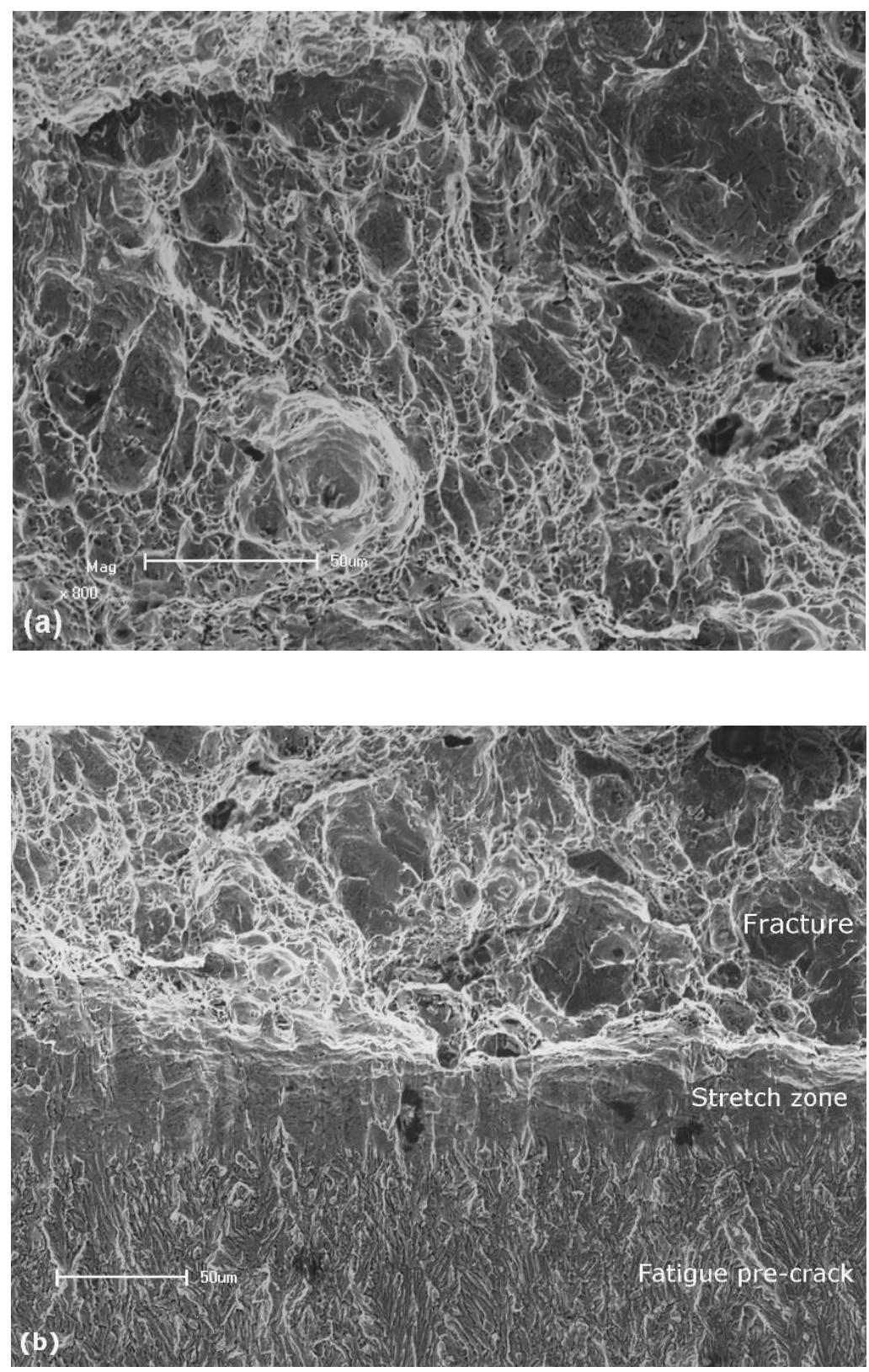

Figure 4: Fractographic of SSS specimen after fracture toughness test in air. (a) Ductile fracture by dimples;

(b) Presence of stretch zone resulted from crack blunting.

The assisted environment fracture toughness tests (step loading tests) were performed in synthetic seawater environment with steel submitted to cathodic protection at $-1.100 \mathrm{mV}_{\mathrm{xSCE}}$ simulating a steel "overprotection" condition. In these results, the required $\mathrm{K}$ values to fracture the specimens were $61 \mathrm{MPa} \vee \mathrm{m}$ and $56 \mathrm{MPa} \sqrt{\mathrm{m}}$, these values correspond to a loading of 626 and $667 \mathrm{Kgf}$, respectively. The fractographic analyses 
Fracture toughness evaluation of supermartensitic stainless steel submitted to cathodic protection in seawater environment

Gabriel Pieta Dias, Afonso Reguly, Telmo Roberto Strohaecker

showed a quasi-cleavage brittle fracture together presence of some delaminations, as showed in Figure 5a. Furthermore, it was observed the absence of stretch zone (Figure 5b), which indicates that fracture mode passed from ductile to brittle when assisted by the environment studied. Both specimens tested presented the same fracture characteristics. Since cathodic protection can play role as a hydrogen source leading to hydrogen charging in the steel surface and creating favorable conditions to generate embrittlement phenomenon, the protected steels might suffer from hydrogen damages (Stroe, 2006). It is generally agreed that the resistance to hydrogen embrittlement of steels depends on the microstructure, strength level and hydrogen concentration (Tsay et al., 2007). High strength steels and martensitic microstructures can be more susceptible to this phenomenon, such as SSS (Nagumo et al., 2001). In the presence of cracks, such as the case of specimens used in step loading tests, hydrogen has a tendency to move towards crack tip due the presence of a state of triaxiality of stress and a plastic zone in this region (Gingell, 1997) becoming more aggressive as an embrittling agent (Bilmes et al., 2001).

The main factor for degradation of fracture toughness properties of SSS were attributed to the deleterious effect from $\delta$-ferrite, which has low hydrogen solubility and high hydrogen diffusibility, facilitating hydrogen transport into steel and, thus, increasing susceptibility to hydrogen embrittlement. On the other hand, one could expect that the presence of austenite in the martensitic matrix of SSS would improve the hydrogen embrittlement resistance of the steel by decreasing of hardness, increasing the number of strong traps of hydrogen, such as the interface between austenite and the matrix, and lowering the diffusion rate of hydrogen in the steel (Tsay et al., 2007).

The absence of a stretch zone at the crack propagation front when assisted by environment supports the assessment fracture in the linear elastic regime. By these reason one can define the $K$ value of fracture as $\mathrm{K}_{\mathrm{IEAC}}$ value for SSS in the environment studied. However, according to ASTM E399-90 (American Society for Testing and Materials, 1997), the maximum thickness for CT specimens that was possible to obtain from SSS pipeline for this study, it was $6.10 \mathrm{~mm}$, does not make possible a valid $\mathrm{K}_{\mathrm{IC}}$ measurement, since this material presents a high toughness. Thus, this $\mathrm{K}$ value measured was defined as the fracture toughness for this specific thickness of material in the environment studied.

\section{Conclusions}

- The presence of $\delta$-ferrite did not significantly affect the ductile of SSS in air.

- The studied SSS showed susceptible to hydrogen embrittlement when submitted to cathodic protection at a condition of over-protection in seawater environment.

- The steel presented a large decrease in fracture toughness property in the environment studied due to hydrogen effect, resulting in loss of material plasticity with fracture transition from ductile to brittle mode.

- The large amount of $\delta$-ferrite in the steel was attributed as the main factor for fracture toughness decreasing when assisted by environment due to its deleterious effect on hydrogen embrittlement resistance. 
Fracture toughness evaluation of supermartensitic stainless steel submitted to cathodic protection in seawater environment

- The absence of stretch zone at the crack front support that fracture occurred in linear elastic regime when assisted by environment, while fracture in air occurred in elastic-plastic regime.
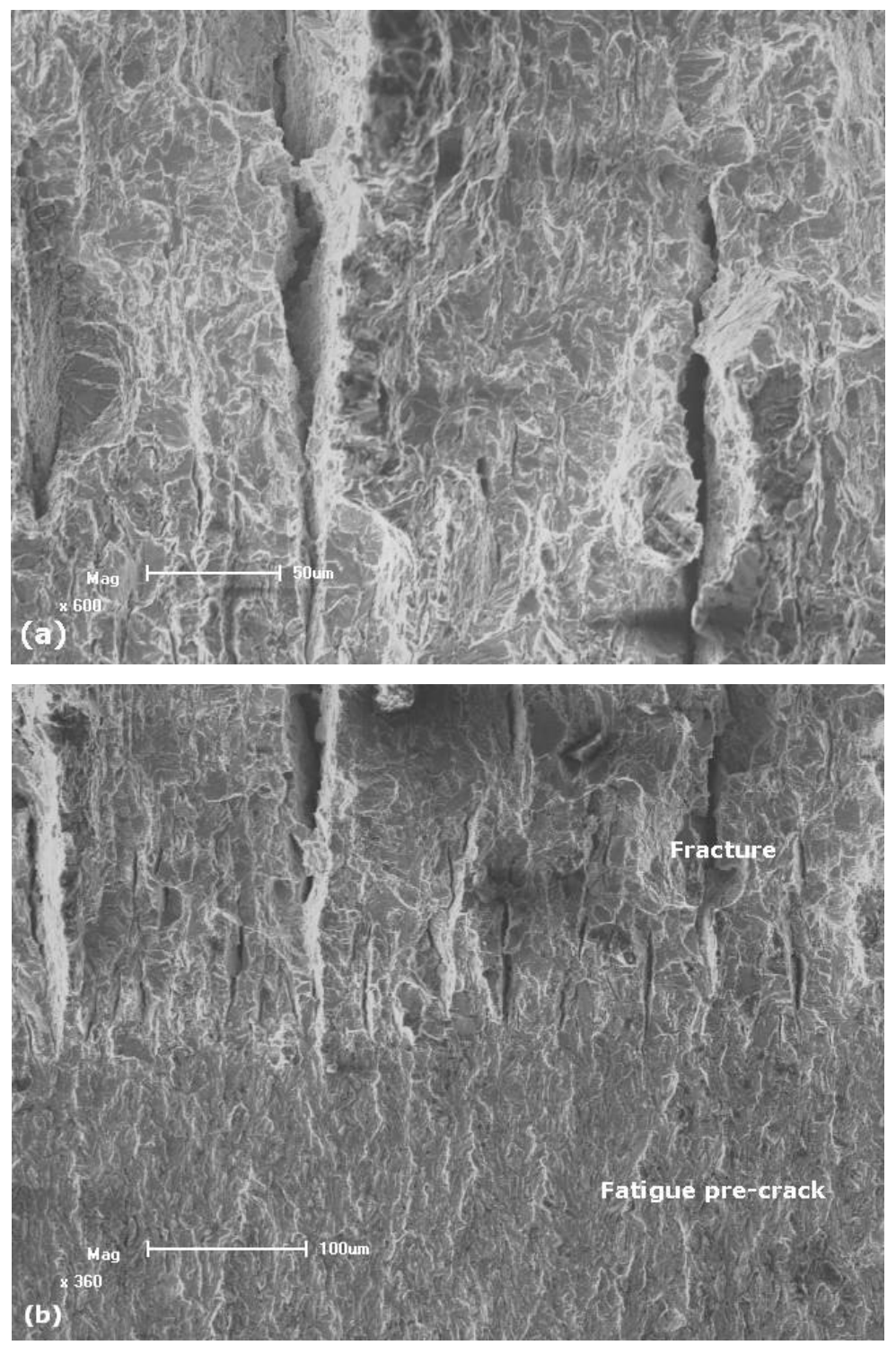

Figure 5: Fractographic of SSS specimen after fracture toughness test assisted by environment.

(a) Quasi-cleavage brittle fracture; (b) Image showing the absence of stretch zone.

\section{Acknowledgement}

The authors would like to acknowledge the financial support of CNPq. 
Fracture toughness evaluation of supermartensitic stainless steel submitted to cathodic protection in seawater environment

Gabriel Pieta Dias, Afonso Reguly, Telmo Roberto Strohaecker

\section{References}

AMERICAN SOCIETY FOR TESTING AND MATERIALS. 1997. ASTM E399-90. Standard test method for planestrain fracture toughness of metallic materials.

ANDERSON, T.L. 1995. Fracture mechanics: Fundamentals and applications. $2^{\text {nd }}$ ed., Texas, Texas A\&M University - Department of Mechanical Engeneering, $681 \mathrm{p}$.

BALA SRINIVASAN, P.; SHARKAWY, S.W.; DIETZEL, W. 2004. Environmental cracking behavior of submerged Arc-Welded supermartensitic stainless steel weldments. Journal of Materials Engineering and Performance, 13:232-236.

BILMES, P.D.; SOLARI, M.; LLORENTE, C.L. 2001. Characteristics and effects of austenite resulting from tempering of $13 \mathrm{Cr}-\mathrm{NiMo}$ martensitic steel weld metals. Materials Characterization, 46:285-296.

CARROUGE, D.; BHADESHIA, H.K.D.H.; WOOLLIN, P. 2004. Effect of $\delta$-ferrite on impact properties of supermartensitic stainless steel heat affected zones. Science and Technology of Welding and Joining, 9(5):377-389.

GINGELL, A. 1997. A bibliographical study of hydrogen trapping and embrittlement in linepipe steels. In: IRSID Usinor Sacilor, Rapport Interne, p. 1-15.

KONDO, K.; UEDA, M.; OGAWA, K.; AMAYA, H.; HIRATA, H.; TAKABE, H.; MIYAZAKI, Y. 1999. Alloy design of Super $13 \mathrm{Cr}$ martensitic stainless steel (Development of Super $13 \mathrm{Cr}$ martensitic stainless steel for line pipe). In: Supermartensitic Stainless Steel, Brussels, Belgium, 1999. Proceedings... Brussels, p. 11-18.

MARCHEBOIS, H.; LEYER, J.; ORLANS-JOLIET, B. 2007. SSC performance of a Super 13\%Cr martensitic stainless steel for OCTG: Three-dimensional fitness-for-purpose mapping according to $\mathrm{P}_{\mathrm{H} 2 \mathrm{~S}}, \mathrm{pH}$ and chloride content. NACE 07090.

MIYATA, Y.; KIMURA, M.; KOSEKI, T. 2006. Martensitic stainless steel seamless pipe for linepipe. JFE Technical Report, 7:14-19.

MIYATA, Y.; KIMURA, M.; MASAMURA, K. 2007. Effects of chemical components on resistance to intergranular stress corrosion cracking in supermartensitic stainless steel. NACE 07092.

NAGUMO, M.; NAKAMURA, M.; TAKAI, K. 2001. Hydrogen Thermal Desorption Relevant to Delayed-Fracture Susceptibility of High-Strength Steels. Metallurgical and Materials Transactions, 32A:339-347. 
Fracture toughness evaluation of supermartensitic stainless steel submitted to cathodic protection in seawater environment

Gabriel Pieta Dias, Afonso Reguly, Telmo Roberto Strohaecker

POURBAIX, A. 1999. Cathodic protection of supermartensitic $13 \mathrm{Cr}$ stainless steels without hydrogen damage. In: Supermartensitic Stainless Steel, Brussels, Belgium, 1999. Proceedings... Brussels, p. 283-290.

RAMIREZ, J.E. 2007. Weldability Evaluation of Supermartensitic Stainless Pipe Steels. Welding Journal, 86: $125-132$.

ROGNE, T.; DRUGLI, J.M.; BJORDAL, M. 1999. EAC Testing of Welded $13 \% \mathrm{Cr}$ Grades Martensitic Stainless Steels for Sour Service Applications. In: Supermartensitic Stainless Steel, Brussels, Belgium, 1999. Proceedings... Brussels, p. 323-330.

ROŽNOVSKÁ, G.; VODÁREK, V.; KORČÁK, A.; TVRDÝ, M. 2005. The effect of heat treatment on microstructure and properties of a $13 \mathrm{Cr} 6 \mathrm{Ni2}$.5Mo supermartensitic steel. Sborník vědeckých prací Vysoké školy báňské - Technické univerzity Ostrava, 48:225-231.

STROE, M.E. 2006. Hydrogen Embrittlement of Ferrous Materials. Bruxelles, Belgium. D.Sc. Thesis. Faculty of Applied Sciences - Université Libre de Bruxelles, 236 p.

TSAY, L.W.; CHEN, H.H.; CHIANG, M.F.; CHEN, C. 2007. The influence of aging treatments on sulfide stress corrosion cracking of PH 13-8 Mo steel welds. Corrosion Science, 49:2461-2473.

Submissão: $28 / 08 / 2008$

Aceite: $17 / 10 / 2008$ 